\title{
The determinants of secondary jobholding in Germany and the UK
}

\author{
Guido Heineck
}

Accepted: 9 December 2008 / Published online: 12 March 2009

(C) Institut für Arbeitsmarkt- und Berufsforschung 2009

\begin{abstract}
Secondary jobholding is a persistent phenomenon in both Germany and the UK. Using panel data from the BHPS and the SOEP, reduced form participation equations are estimated for male and female workers separately. Whereas the results vary across gender and countries, there is support for both main theoretical strands, i.e. for the 'hours-constraints' motive and, though less clear, for the 'heterogeneous-jobs' motive.
\end{abstract}

\section{Determinanten der Nebenerwerbstätigkeit in Deutschland und im Vereinigten Königreich}

Zusammenfassung Nebenerwerbstätigkeit ist ein beständiges Phänomen sowohl in Deutschland wie auch im Vereinigten Königreich. Mit Paneldaten des BHPS und des SOEP werden reduzierte Partizipationsgleichungen getrennt für Männer und Frauen geschätzt. Zwar finden sich nach Geschlecht und Land variierende Ergebnisse, jedoch findet man Evidenz für beide theoretischen Hauptmotive der Nebenerwerbstätigkeit, nämlich dem Motiv rationierter Arbeitsstunden und, jedoch weniger deutlich, dem Motiv heterogener Beschäftigung.
G. Heineck (匹)

Institute for Employment Research (IAB),

Weddigenstraße 20-22, 90478 Nuremberg, Germany

e-mail: guido.heineck@iab.de

\section{Moonlighting: ${ }^{1}$ an introduction}

The supply of labor in more than one job has not been on the top of labor economists' agendas for long. Although there is an established literature, it is far from extensive. In contrast to the ever increasing literature on atypical employment, multiple jobholding as another facet has by and large gone unnoticed. This is somewhat surprising as this form of labor supply is as closely related to changes in labor market institutions and regulations, as for example part-time and fixed term employment. Furthermore, moonlighting is a rather widespread phenomenon in most of the Western industrialized countries. For the US and Canada, several studies by official labor statistics bureaus provide (mainly descriptive) evidence for moonlighting trends over time (Stinson 1997; Sussman 1998).

As will be shown in more detail below, secondary jobholding in Germany has slightly decreased from about $9 \%$ in the mid-1980s (Schwarze 1991) to rates of about 6\% at the end of the 1990s (Schwarze 1997; Schwarze and Heineck 1999; Heineck and Schwarze 2001) and the early 2000s. For the UK, Bell et al. (1997) and Böheim and Taylor (2004a) report moonlighting rates of about $10 \%$ for the period between 1991 and 1998.

The exploratory analysis in this paper adds to the literature in several ways. First, with the exception of Kimmel and Powell (1999) and Renna (2006), cross-country comparisons have not been carried out before. This is even more important here since Germany and the UK are proponents of very different labor market regimes: whereas the UK labor market regime is liberal, the German labor market is

\footnotetext{
${ }^{1}$ Note that the term 'moonlighting' is used interchangeably with 'secondary jobholding' or 'multiple jobholding' and that there are no implications in terms of legitimacy.
} 
restrictive in several aspects (for more details see below). Sousa-Poza and Henneberger (2002) further show that hours-constraints have increased in Germany and decreased in the UK between 1989 and 1997. As hours-constraints on the main job are the most prominent theoretical argument with regard to secondary jobholding, the comparison between Germany and the UK can help to explore underlying determinants other than labor market constraints. The study furthermore explores the determinants of moonlighting behavior separately for males and females which has been done only by a few studies before (e.g. Schwarze 1991; Averett 2001). In addition, while most of the previous research uses cross-sectional data, this study explores panel data so that unobservable heterogeneity can be controlled for.

While there are some differences by country and gender, the findings yield support for both main theoretical strands, i.e. for the 'hours-constraints' motive and, though less clear, for the 'heterogeneous-jobs' motive. However, hoursconstraints seem to play a bigger role for German workers, which fits the picture of the strongly regulated labor market limiting workers' earnings capacity on the first job.

\section{Background: motives, institutions and previous findings}

\subsection{Motives}

When asking workers why they supply labor in more than one job, answers show that financial concerns are the main motivation to moonlight. With $30-35 \%$, the most often stated reason for working in more than one job of moonlighters is the 'need to meet regular household expenses' (Stinson 1997; Sussman 1998; Averett 2001). The primary explanation for secondary jobholding therefore used to be the notion of a fixed amount of hours an individual is allowed to work on her main job. If the number of realizable hours is below the desired level, labor supply constraints exist that keep the worker from earning sufficient income. There might then be an incentive to adjust the difference between desired and realized hours of work by offering labor in a second job.

There are also other possible moonlighting motives. While $10-15 \%$ of moonlighters want to 'gain experience to build up a business', more than $15 \%$ simply 'enjoy the work on the second job' (ibid.). These findings hint towards additional motives for moonlighting other than hours-constraints. There consequently are a few studies that extend the initial theoretical background by ideas that are subsumed under the so-called 'heterogeneous-jobs' motive. In general, this refers to jobs that are not perfect substitutes. Typical examples are the university professor who uses her expertise in consulting or the musician who cannot make a living from her performances only and thus holds a regular job to keep up to her expenses. Mothers of young children are another example since they may hold two part-time jobs that suit their time-allocation needs of arranging child care better than one full-time occupation.

\subsection{Institutions}

As outlined above and as can be derived from theoretical reasoning (see below), hours-constraints are important moonlighting determinants. Institutional settings therefore are relevant since they may either allow or hinder individuals' labor supply decisions in general and with respect to working time. The present analysis sheds light on two countries that differ strongly in labor market institutions: the German labor market is highly regulated, imposing quite a few restrictions on workers' decisions. Liberal regimes, such as the British, might on the other hand offer a wide range of options by which a worker might adjust in order to achieve maximum utility.

Evidence for differences in labor market regimes is provided, for example, by the OECD (OECD 1999) or Nickell et al. (2005), both referring to the late 1990s. Measuring overall strictness of employment protection legislation on a scale from 0 to 6 , the UK has a score of 0.5 whereas Germany's score is 2.6. That is, among the 26 OECD countries analyzed, Germany ranks at position 20 with only the South European countries having even stricter employment protection legislation. The UK on the other hand ranks at
Table 1 Labor market institutions in Germany and the UK, late 1990s

\begin{tabular}{lcc}
\hline & Germany & UK \\
\hline Employment legislation strictness (index, range 0 to 6) $^{\mathrm{a}}$ & & \\
- regular employment & 2.8 & 0.8 \\
- temporary employment & 2.3 & 0.3 \\
- overall & 2.6 & 0.5 \\
Collective bargaining coverage (\%) & 92 & 40 \\
Union density $^{\mathrm{b}}$ & 27 & 35 \\
\hline
\end{tabular}

Source: ${ }^{a}$ OECD 1999; ${ }^{\text {b }}$ Nickell et al. 2005 
position 2, i.e. has the most liberal labor market regime following the US which has mainly no labor market restrictions (Table 1).

While Germany and the UK further differ, for example, in aspects such as maternity leave regulations (Schmitt 2008) institutional settings that are more likely to affect secondary jobholding are union density and collective bargaining coverage since both wage and hours setting schemes are covered particularly by the latter. Table 1 shows no large differences in union density at the end of the 1990s. Collective bargaining coverage, however, strongly differs between Germany and the UK, with $92 \%$ and $40 \%$ respectively.

It might further be argued that with only a few or no regulations specifically on working time, workers may have fewer incentives to moonlight: in such a case, it may be expected that workers would be able to realize their desired working hours level. This argument is, however, based on the 'hours-constraints' motive only. The empirical analysis might therefore allow exploring whether differences in the labor market regime come along with differences in the determinants of secondary jobholding other than or in addition to hours-constraints.

\subsection{Previous findings}

The existing research on multiple jobholding covers a wide range of both theoretical and empirical topics. Shishko and Rostker (1976) were the first who combined theoretical reasoning with empirical analyses. While they acknowledge that there might be reasons for moonlighting other than hours-constraints on the main job, the empirical part of their analysis is based on that rationale only. More recent research also addresses other motives and different issues of interest. In particular, Schwarze (1991) extends the theoretical background by explicitly incorporating job-quality in the model. His findings, which are based on cross-sectional data from the German SOEP, reinforce the importance of this extended model.

The link between labor supplied in the first and the second job is analyzed by Smith Conway and Kimmel (1998) for US males. Their findings indicate a) support of both the 'hours-constraints' and the 'heterogeneous-jobs' motive and b) that male labor supply is far more elastic than usually assumed once moonlighting is incorporated in labor supply behavior.

The dynamics of dual jobholding have been the focus of Böheim and Taylor (2004a) as well as of Paxson and Sicherman (1996). The duration of moonlighting is addressed by Marshall (2002) and Kimmel and Smith Conway (2001). Again, the main results are consistent with the presence of multiple motives for dual jobholding, with the 'hours-constraints' motive being the most common. Amuedo-Dorantes and Kimmel (2005) examine the cycli- cality of multiple jobholding and find support for procyclical behavior of moonlighters.

Gender differences in moonlighting behavior and moonlighting wages have been explored by Averett (2001) who does not find substantial differences in the factors leading men and women to moonlight. Yet, the results AmuedoDorantes and Kimmel (2005) indicate that female moonlighters are much more likely to combine a full-time primary job with a part-time secondary job, while male moonlighters are more likely to hold two full-time jobs. In general, gender differences may be induced by e.g. family responsibilities and occupational segregation (Highfill et al. 1995; Allen 1998).

Renna (2006) provides cross-national evidence for the relationship between overtime and secondary jobholding. Using LES data, he concludes that decreasing the standard weekly working hours as well as raising overtime premiums increases secondary labor supply.

\section{Theoretical framework}

The standard theoretical framework employed in the analysis of moonlighting is a straightforward extension of the static labor-leisure model by implementing hoursconstraints. Shishko and Rostker (1976) argue that a worker who cannot spend as much time in her main job as she wants to in order to realize utility maximizing hours of work may have an incentive to supply labor in a second job. They derive a set of testable implications from comparative statics that are also adapted by Smith Conway and Kimmel (1998) as well as Böheim and Taylor (2004a) and are therefore not repeated in this analysis in detail. In a nutshell, the static theory postulates the following three main scenarios:

1. Upwards-hours-constrained workers will gain from moonlighting because of reaching a higher utility level (a graphical illustration of this notion can be found in Averett 2001); as a consequence, second job wages will be lower than first job wages, $w_{2}<w_{1}$.

2. Implausible as it may appear at first glance, there is also an incentive to moonlight for a downwards-hoursconstrained worker if the second job wage at least maintains the worker's utility level; in this case however, second job wages have to be much higher than first job wages, $w_{2}>w_{1}$.

3. The situation is different for the non-hours-constrained worker inasmuch as she theoretically can freely choose any working time on the first job. The 'heterogeneousjobs' motive however suggests that it is not wages that matter most but other amenities or benefits that come along with either job. Jobs may also be complements according to this theoretical notion. Second job wages may 
then be higher or lower than first job wages. Standard examples for this scenario are a) the musician who holds a regular job for social security reasons but is willing to accept a low-paid second job - as a pianist in a bar for example - that may be more fulfilling individually; b) in line with the complementary character of jobs like the university professor who needs her position and reputation to be able to engage in high-wage consulting.

As an extension to the standard model, Schwarze (1991) examines the effects of heterogeneous jobs by including a 'job-quality' factor for both main and moonlighting job in the individual's utility function. While it would be desirable to have clear cut theoretical propositions, he shows that the quality of both jobs is ambiguously affiliated to multiple jobholding. In particular, whether improving working conditions on the first job implies an increase in moonlighting depends on whether the increase in job quality results in a higher marginal utility of leisure. If so, moonlighting will decrease. It however may also be that poor working conditions on the main job enhance the need to regenerate in the spare time. Analogously, assuming improving working conditions, leisure might then not be needed that much to recover from stress. Secondary jobholding may then increase.

While the analysis of moonlighting hours is an interesting endpoint in itself, the following empirical analysis focuses on the participation decision and explores both hoursconstraints and 'job quality' factors which includes formal settings such as part-time or fixed-term employment but also individual conditions such as dissatisfaction with job security or work itself.

\section{Data, expectations and descriptive findings}

\subsection{Data and expectations}

The data are drawn from the German Socio-Economic Panel (SOEP) for Germany (Wagner et al. 2007) and the British Household Panel Survey (BHPS) for the UK (Taylor et al. 2008). Both surveys are nationally representative studies providing detailed information on individual and household related characteristics on an annual basis. The SOEP started in 1984, the BHPS was implemented in 1991. Both surveys provide a large range of questions concerning secondary jobholding. Since the questionnaires are not directly comparable there however are differences in questions and wording that should be kept in mind.

\subsubsection{Hours-constraints}

Unlike, for example, the special supplement of the 1991 CPS on moonlighting, there is no question in either survey as to why a worker holds a second job. Such an item would allow differentiating between a constrained and an unconstrained moonlighter. There however is a variety of indicators that help to identify whether it is because of hoursconstraints or because of other reasons a worker might take a second job.

Above all, both surveys provide questions on the individual's preferences over hours worked. The BHPS directly asks for preferences, whereas the SOEP asks for the desired number of hours. ${ }^{2}$ Comparing the number of desired hours with the number of hours usually worked per week allows generating appropriate indicators.

While there might be the usual caveats regarding subjective indicators, analyses show that the reported dissatisfaction with hours worked reflects actual restrictions on the choice of hours (Bryan 2007). There is also evidence that subjective reports on constraints predict adjustments in working hours by for example a change of job (Böheim and Taylor 2004b). If hours-constraints exist and if a job-change cannot be realized in the short run, workers might adjust their working hours by moonlighting.

\subsubsection{Job-quality}

Further questions on job related satisfaction are used to derive indicators on dissatisfaction with a) job security, b) total pay (BHPS)/household income (SOEP), c) work itself. In accordance with the theoretical arguments regarding job quality, a priori expectations towards the effects of dissatisfaction with job security are ambiguous. It might be, for example, that secondary jobholding serves as a hedge against unemployment (Bell et al. 1997). Yet, it may also be possible that workers take even more efforts to perform well in their first job and are therefore less inclined to moonlight. As Schwarze (1991, p. 228) points out, it may as well be that less favorable labor market conditions that lead to concerns about job security in the first place may inhibit one to supply a second job. ${ }^{3}$

Another indicator for low job quality is dissatisfaction with work itself. In contrast to job security, it might well be that a worker who is dissatisfied with her first job may be more likely to hold a second job: if work itself is not satisfying, but, for example, provides financial stability, an individual might moonlight if the second job provides amenities other than monetary benefits. ${ }^{4}$

\footnotetext{
${ }^{2}$ While it cannot be disentangled whether respondents refer to working hours of both first and second job, the question is placed among primary job related questions. It may thus be plausible to assume that responses refer to the individual's main job.

${ }^{3}$ Note again the evidence in support of pro-cyclical moonlighting behavior (Amuedo-Dorantes and Kimmel 2005).

${ }^{4}$ It might however be expected that the individual will in the middle or long run change to a new job that provides both monetary and other benefits.
} 
Dissatisfaction with total pay or household income might hint towards a limited earnings capacity that may move workers to take a second job since it is plausible to assume that this type of dissatisfaction is caused by 'too low' earnings or income.

Temporary employment might as well be an indicator for job quality, but again with ambiguous expectations towards the effect on moonlighting behavior. Since a fixed-term contract might be used for a probationary period with prospects for a permanent follow-up employment, a worker may have an incentive to take strong efforts within that period to signal high productivity. Holding a second job may then be less likely. Having a temporary job may also be a demand-side induced outcome of lower productivity. Secondary jobholding may therefore be used as means of adapting to the possibly low labor market position.

Both BHPS and SOEP provide more questions on expectations on current and future work which might also be used as indicators of job quality. Additional regressions that explore the impact of these indicators have been run but are not presented as the results do differ substantially from the findings provided below. ${ }^{5}$

\subsubsection{Pay and income}

Information about gross hourly wages in either the first or second job can be derived from the data that is given on monthly earnings and the number of hours usually worked per week. The BHPS provides data on earnings in a second job in each wave but the SOEP provides this data only from 1995 onwards. Non-labor income is generated by subtracting a worker's first- and second-job earnings as well as the spouse's labor earnings from the overall net householdincome.

\subsubsection{Working time}

Working overtime and getting overtime hours paid points to hours and earnings adjustments that might have a negative effect on moonlighting if the 'hours-constraints' motive prevails. Expectations regarding part-time jobs are ambiguous because such occupation might be voluntary or involuntary: if part-time jobs are accompanied with moonlighting, this might, on the one hand, hint towards an insufficient hours capacity on the first job. It might, on the other hand, support the 'heterogeneous-jobs' motive as working part-time on a stable and secure job might allow to take a second job that has other non-monetary amenities. Furthermore, hold-

\footnotetext{
${ }^{5}$ For example, workers who aim at starting up an own business in the next future are more likely to hold a second job; expecting to quit from paid employment on the other hand is related with a lower propensity to moonlight.
}

ing two part-time jobs might simply be a means of workers' labor flexibility.

\subsubsection{Controls}

The regressions, furthermore, include a variety of socioeconomic and other job characteristics. ${ }^{6}$ These are: age and age squared, educational dummies, whether the individual is married, whether the spouse is employed, two dummies indicating the presence of dependent children aged 0 to 4 years or 5 to 15 years and regional dummies. Job-related controls are: public employer, duration of employment, firm-size, industry dummies, and occupational dummies. To account for possible adjustments to desired working hours by a change of job, there is a further dummy variable indicating whether the individual has changed to the current job only recently, i.e. whether job duration is less than one year. Expectations on these covariates will not be discussed to save space.

The samples are restricted to blue- or white-collar workers aged 17 to 60 who are full- or part-time employed on their first job. The BHPS sample includes data from 1991 to 2006 and consists of 40,733 male and 43,591 female person-year-observations. The German sample is also an unbalanced panel and includes data from 1995 and 1997 to $2007 .{ }^{7}$ It comprises 54,046 male and 47,543 female person-year observations.

\subsection{Descriptive findings}

To give some first impressions about the structure of secondary jobholding in both Germany and the UK, descriptive findings are presented in Figs. 1 and 2. Figure 1 shows that moonlighting is a persistent phenomenon in both countries. There is, however, some variation by gender and overtime, possibly indicating cyclical influences (see also AmuedoDorantes and Kimmel 2005) but also changes in the institutional framework. ${ }^{8}$

In line with the results of Böheim and Taylor (2004), British women moonlight more often than men. Yet, the difference in participation is rather stable over time. In contrast, German women used to moonlight less often than males

\footnotetext{
${ }^{6}$ See the Appendix, Table 5, for descriptive statistics.

${ }^{7}$ Data for 1996 are not included since preferences on working hours are not given for this year.

${ }^{8}$ In Germany, there were substantial institutional changes for so-called marginal employment: in 1999, social-security contributions for this type of employment were introduced but again abolished in 2003. While the introduction had a short-term negative effect on moonlighting (Heineck and Schwarze 2001) the abolishment was accompanied by an increase in secondary jobholding (Caliendo and Wrohlich 2006). However, since that the patterns are quite similar in both countries cyclical effects cannot be ruled out. Yet, a more detailed analysis on this issue is beyond the scope of this paper.
} 

Germany and the UK, by gender
Fig. 1 Moonlighting in

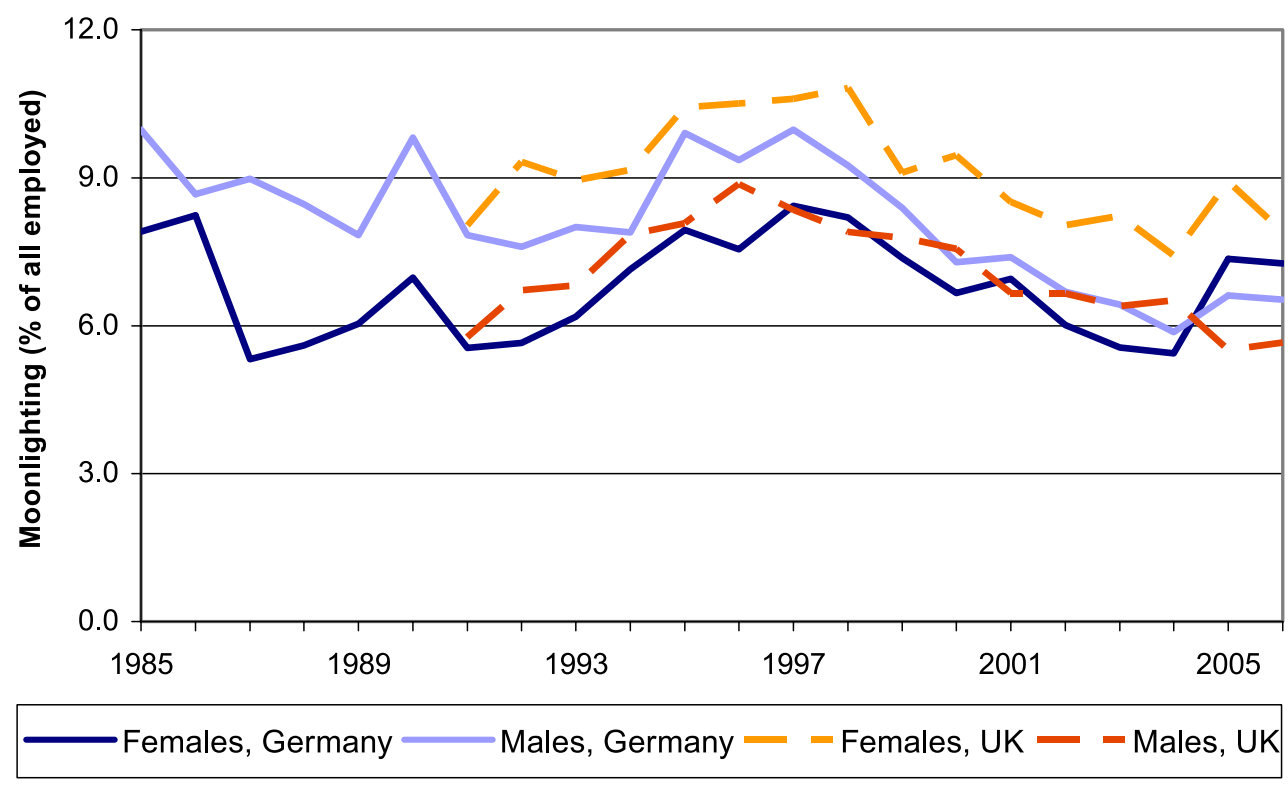

Fig. 2 Moonlighting in Germany and the UK, by full- and part-time employment

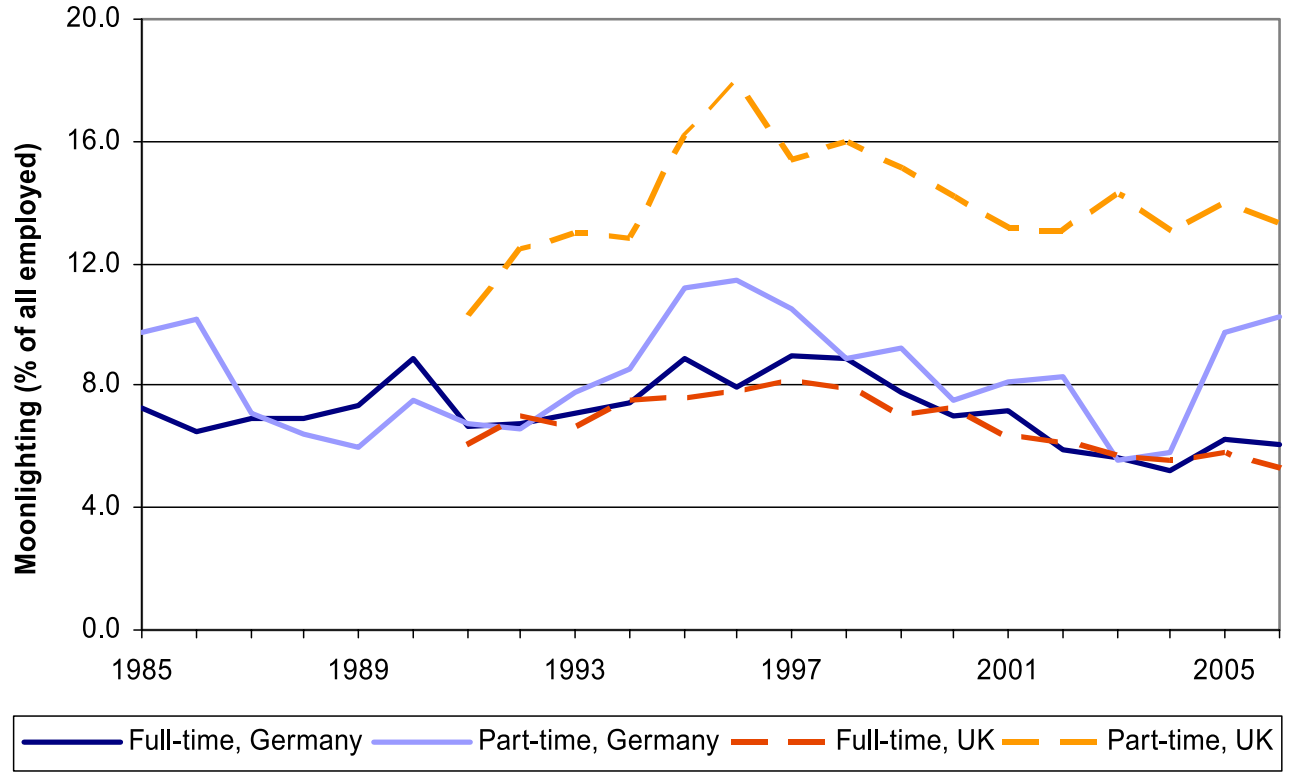

until 2004. For 2005 and 2006 however, women moonlight more often than men. ${ }^{9}$

Figure 2 shows that variation over time is mainly induced by the changes in secondary jobholding by part-time employees: There is a strong increase in moonlighting by parttime workers in both Germany and the UK from the beginnings of the 1990s until 1996, reaching a level of almost $12 \%$ moonlighters in Germany and $18 \%$ in the UK. There-

\footnotetext{
${ }^{9}$ See also Hirschenauer and Wießner (2006) who use data from the Beschäftigten-Historik $(\mathrm{BeH})$ which covers all employees who are liable for social insurance but not self-employed and public servants. Their findings indicate that moonlighting is more prevalent among female worker already in 2004.
}

after, secondary jobholding by part-time workers decreases again in both countries. While moonlighting among German workers drops back to the level of the early 1990s it remains on a rather high level for part-time workers in the UK.

There are only little changes over time for full-time workers except for German workers in 1990 when secondary jobholding shows a peak, possibly as a consequence of German reunification. Furthermore, as part-time employment is the domain of women, it is not surprising that differences in participation rates between full- and part-time employees mainly follow the profiles by gender shown above.

Without showing it in detail, note that the number of weekly hours worked in a second job ranges between 5 and 7 hours per week for both German and British workers 
Table 2 Working time preferences, moonlighting incidence and wage ratios in Germany and the UK

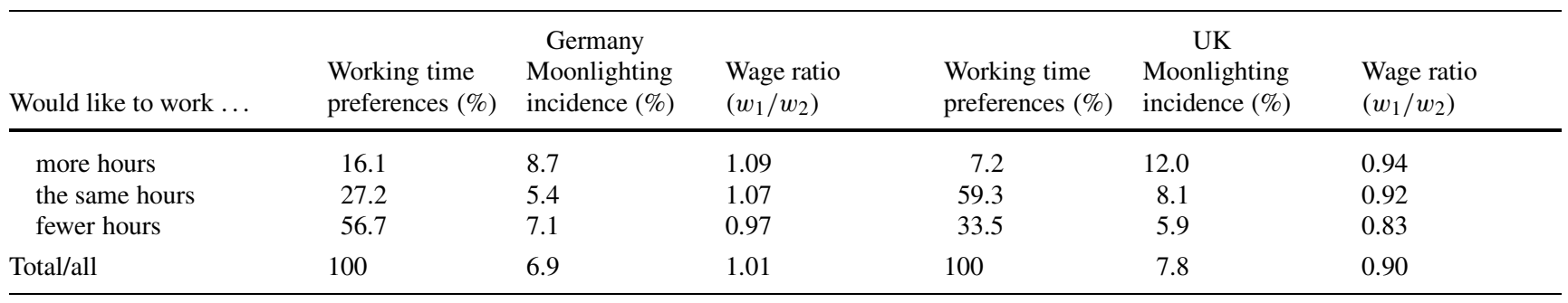

Source: SOEP; BHPS. Own calculations

in the observed period. There is, however, no distinct pattern.

Descriptive evidence for hours-constraints and the relationship to moonlighting are given in Table 2. First, the most striking finding is the difference in the distribution of preferences over hours worked which very likely reflects differences in the labor market regimes: almost $60 \%$ of British workers are satisfied with working time, i.e. are able to realize their optimal labor supply level. In contrast, only $27 \%$ of German workers do not want to change their working time. Yet, it is interesting to note that more than half of all employed persons want to work fewer hours. Rather than being restricted upwards, those workers suffer from downwards constraints. In accordance with upwards restrictions it can furthermore be seen that some $7 \%$ of British workers and about $16 \%$ of German workers would like to work more hours.

More differences appear regarding participation in moonlighting and the ratio of wages in both jobs. Since British workers who are satisfied with their working hours and German workers who would rather work less make the largest group respectively, it is not surprising that these individuals do not moonlight much more or less than average. In contrast, moonlighting among workers who want to work more is clearly above average: two percentage points for German workers and more than four percentage points for their British counterparts. ${ }^{10}$

German moonlighters who are either satisfied with their working time or who would prefer to work more hours earn second job wages that are lower than their primary job wages indicating that those workers might be hoursconstrained on their first job. On the other hand, workers who would prefer to supply fewer hours earn second job wages that are slightly higher than those in the first job. This is in accordance with the theoretical proposition for unconstrained moonlighters as outlined above. For British workers, second job wages are higher than first job

\footnotetext{
${ }^{10}$ Note that incidence rates shown in Table 2 are averages over time but that there has been some up and down particularly for upwards restricted workers.
}

wages irrespective of their preferences over working hours. Workers who would like to work fewer hours, however, earn second job wages that are relatively higher compared to the other two groups of moonlighters.

\section{Methods}

The decision to take on a second job is binary so that standard models can be applied: the probit estimator is used for the analysis of pooled cross-sectional data, adjusting for individual clusters. Regarding the panel models, the random effects probit estimator is employed to allow for comparison with the findings of Böheim and Taylor (2004a) and Amuedo-Dorantes and Kimmel (2005). In addition, the (conditional) fixed effects logit estimator is employed. ${ }^{11}$ To ease interpretation, marginal effects are given for the probit and random effects probit estimations and factor changes in odds ratios for the fixed effects logit estimations.

There are two problematic issues. First, a worker's moonlighting wage on the second job is one of the crucial factors in her participation decision. Yet, secondary wages are observed only for moonlighters so that self-selection problems might play a role. The traditional remedy would be to apply Heckman's correction procedure (Heckman 1979). Without showing details, experiments with different exclusion restrictions do however result in implausible predictions. Following Puhani (2000), predicted moonlighting wages from subsample OLS are used instead since this approach is the most robust among the simple-to-calculate estimators. All regressions have furthermore been estimated without second job wages to check for sensitivity. The results are almost identical so that estimates from the full specification are provided only.

The second potential problem with using first job hours and wages arises from the possible endogeneity of the par-

\footnotetext{
${ }^{11}$ This implies that a contribution to the likelihood arises from only those groups of observations that are not always zero or one. Therefore, if the worker does not moonlight at all or is always moonlighting over the time examined, her information does not enter the likelihood function. This however entails a huge drop in the number of usable observations.
} 
ticipation decision in both main and second job if the worker is not hours-constrained (Smith Conway and Kimmel 1998): a worker might simultaneously decide upon both forms of employment if jobs are heterogeneous. In this case, wages from and hours worked on the first job are not strictly exogenous. This argument suggests either omitting both indicators as regressors, or trying to overcome this drawback by, for example, applying IV estimators. The latter, however, also has shortcomings, particularly in the presence of weak instruments. Experimenting with IV estimations yield implausible results possibly because of this very problem. Again, testing for sensitivity, specifications with and without primary job wages and hours are estimated. Since the differences in the results are not substantial estimates from the full specifications are provided below.

\section{Empirical results}

Note first that findings from the control variables are not provided to save space; full estimation results are available upon request. ${ }^{12}$

\subsection{Results for males}

The results for males indicate that the desire to work more hours is a strong predictor for moonlighting behavior in Germany but not for British workers (Table 3). For German males, the marginal effect after random effects estimation, for example, corresponds to a change in the predicted moonlighting probability of about two percentage points which is qualitatively reinforced by the factor changes of about 1.4 in the fixed effects model. There is a further difference between German and British workers who want to work fewer hours: In the UK, the findings from the panel models suggest a lower propensity to moonlight. In contrast, German workers who are downwards-hours-constrained have a higher propensity to hold a second job, even controlling for individual specific effects. While this might seem surprising at first glance, this result may arise from higher wages achieved in the second job (cf. Table 2). ${ }^{13}$

Whereas dissatisfaction with work itself is not related to males moonlighting in both countries, dissatisfaction with

\footnotetext{
${ }^{12}$ In a nutshell, working with a public employer is positively associated with moonlighting among both German and British males; having children and having an employed spouse is negatively related to the moonlighting propensity of females in both countries. There furthermore are no clear-cut patterns for age, education, marital status and the other covariates.

${ }^{13}$ It may furthermore be that SOEP respondents answer the hourspreferences question referring to both first and second job so that this finding would come from 'reverse causality'. There however is no way to disentangle whether the respondents refer to only their main job or to both jobs.
}

job security is negatively associated with second jobholding among Germans in the pooled probit and the random effects probit models. Rather than using a second job as a hedge against unemployment, it may more be the case that less favorable labor market conditions which inhibit secondary jobholding also lead to concerns about job security. The results for dissatisfaction with pay or household income then are in line with the hours-constraints motive: moonlighting propensity is higher for both German and British males. While factor changes in the fixed effects regressions are not statistically significant, the coefficients suggest an increase in the predicted moonlighting probability of about one percentage point in both Germany and the UK.

Predicted second job wages are by and large positively related to the moonlighting participation of German males only. Again, this may be related to moonlighting wages being higher in Germany. Furthermore, in line with the implications from the hours-constraints motive, a man's first job wage is negatively associated to his moonlighting propensity. While the association is somewhat weaker for German males, predicted moonlighting probability of British workers decreases by two percentage points (probit models) and by a factor change of 0.4 (fixed effects). Non-labor income plays a role for German males only indicating a lower propensity of holding a second job with higher non-labor income levels. Weekly working hours on the other hand are statistically related to moonlighting for UK males only. The results however indicate only a small decrease in predicted probabilities of about 0.1 percentage points and a factor change of 0.97 .

There is somewhat mixed evidence regarding overtime and its compensation. First, the findings from the probit regressions suggest that working overtime is positively related to moonlighting for Germans only. While this may seem puzzling at first glance, note that working overtime can be compensated by additional pay or by leisure. Additional experiments with indicators that are available for the SOEP only suggest that compensation by leisure comes into play here. Since there is no similar indicator for the BHPS, this cannot be tested more thoroughly.

Paid overtime hours on the other hand are negatively associated with British males' moonlighting participation: The odds change by a factor of about 0.8 , the predicted probability from the random effects specification decreases by 0.01 percentage point. This finding is unsurprising since those workers are able to adjust a possibly given hoursstandard in their first job by working overtime with the same employer. As it is plausible to assume that overtime hours are compensated with wages that are relatively higher, they do not face the need to moonlight.

Both part-time jobs and temporary employment are good predictors for secondary jobholding among German and, less convincing though, British males. There are large and 
Table 3 Propensity to moonlight in Germany and the UK, males' samples

\begin{tabular}{|c|c|c|c|c|c|c|}
\hline & Probit & $\begin{array}{l}\text { Germany } \\
\text { RE Probit }\end{array}$ & FE Logit & Probit & $\begin{array}{l}\text { UK } \\
\text { RE Probit }\end{array}$ & FE Logit \\
\hline Would like to work more hours & $\begin{array}{l}0.037^{* * *} \\
(0.006)\end{array}$ & $\begin{array}{l}0.020^{* * *} \\
(0.004)\end{array}$ & $\begin{array}{l}1.449^{* * *} \\
(0.139)\end{array}$ & $\begin{array}{l}0.008 \\
(0.006)\end{array}$ & $\begin{array}{l}0.006 \\
(0.005)\end{array}$ & $\begin{array}{l}1.091 \\
(0.129)\end{array}$ \\
\hline Would like to work fewer hours & $\begin{array}{l}0.009^{* * *} \\
(0.004)\end{array}$ & $\begin{array}{l}0.008^{* * *} \\
(0.002)\end{array}$ & $\begin{array}{l}1.257^{* * *} \\
(0.095)\end{array}$ & $\begin{array}{l}-0.0004 \\
(0.003)\end{array}$ & $\begin{array}{l}-0.005^{*} \\
(0.003)\end{array}$ & $\begin{array}{l}0.857^{*} \\
(0.065)\end{array}$ \\
\hline Is dissatisfied with job security & $\begin{array}{l}-0.015^{* * *} \\
(0.004)\end{array}$ & $\begin{array}{l}-0.005^{*} \\
(0.003)\end{array}$ & $\begin{array}{l}0.996 \\
(0.094)\end{array}$ & $\begin{array}{l}-0.005 \\
(0.003)\end{array}$ & $\begin{array}{l}0.0002 \\
(0.003)\end{array}$ & $\begin{array}{l}1.007 \\
(0.079)\end{array}$ \\
\hline ... with pay/household-income & $\begin{array}{l}0.012^{* *} \\
(0.005)\end{array}$ & $\begin{array}{l}0.007^{* *} \\
(0.004)\end{array}$ & $\begin{array}{l}1.137 \\
(0.118)\end{array}$ & $\begin{array}{l}0.008^{* *} \\
(0.003)\end{array}$ & $\begin{array}{l}0.006^{* *} \\
(0.003)\end{array}$ & $\begin{array}{l}1.107 \\
(0.082)\end{array}$ \\
\hline ... with job itself & $\begin{array}{l}-0.007 \\
(0.006)\end{array}$ & $\begin{array}{l}-0.005 \\
(0.004)\end{array}$ & $\begin{array}{l}0.858 \\
(0.104)\end{array}$ & $\begin{array}{l}0.003 \\
(0.004)\end{array}$ & $\begin{array}{l}0.002 \\
(0.003)\end{array}$ & $\begin{array}{l}1.052 \\
(0.089)\end{array}$ \\
\hline Log of second job wage & $\begin{array}{l}0.022^{* *} \\
(0.009)\end{array}$ & $\begin{array}{l}0.007 \\
(0.006)\end{array}$ & $\begin{array}{l}1.389^{* *} \\
(0.205)\end{array}$ & $\begin{array}{l}-0.011 \\
(0.010)\end{array}$ & $\begin{array}{l}-0.001 \\
(0.008)\end{array}$ & $\begin{array}{l}0.771 \\
(0.183)\end{array}$ \\
\hline Log of first job wage & $\begin{array}{l}0.004 \\
(0.005)\end{array}$ & $\begin{array}{l}-0.009^{* *} \\
(0.004)\end{array}$ & $\begin{array}{l}0.715^{* * *} \\
(0.076)\end{array}$ & $\begin{array}{l}-0.021^{* * *} \\
(0.006)\end{array}$ & $\begin{array}{l}-0.027^{* * *} \\
(0.004)\end{array}$ & $\begin{array}{l}0.403^{* * *} \\
(0.055)\end{array}$ \\
\hline Log of non-labor income & $\begin{array}{l}-0.005^{\text {*** }} \\
(0.001)\end{array}$ & $\begin{array}{l}-0.005^{* * *} \\
(0.000)\end{array}$ & $\begin{array}{l}0.876^{* * *} \\
(0.009)\end{array}$ & $\begin{array}{l}0.0004 \\
(0.001)\end{array}$ & $\begin{array}{l}-0.0002 \\
(0.001)\end{array}$ & $\begin{array}{l}0.995 \\
(0.019)\end{array}$ \\
\hline Weekly working hours & $\begin{array}{l}0.0002 \\
(0.000)\end{array}$ & $\begin{array}{l}-0.0007 \\
(0.000)\end{array}$ & $\begin{array}{l}0.994 \\
(0.004)\end{array}$ & $\begin{array}{l}-0.001^{* * *} \\
(0.000)\end{array}$ & $\begin{array}{l}-0.001^{\text {*** }} \\
(0.000)\end{array}$ & $\begin{array}{l}0.967^{* * *} \\
(0.005)\end{array}$ \\
\hline Works overtime & $\begin{array}{l}0.011^{* * *} \\
(0.003)\end{array}$ & $\begin{array}{l}0.006^{* * *} \\
(0.002)\end{array}$ & $\begin{array}{l}1.094 \\
(0.073)\end{array}$ & $\begin{array}{l}0.002 \\
(0.005)\end{array}$ & $\begin{array}{l}0.006^{*} \\
(0.004)\end{array}$ & $\begin{array}{l}1.102 \\
(0.117)\end{array}$ \\
\hline Overtime work is paid & $\begin{array}{l}0.002 \\
(0.004)\end{array}$ & $\begin{array}{l}0.002 \\
(0.002)\end{array}$ & $\begin{array}{l}1.081 \\
(0.083)\end{array}$ & $\begin{array}{l}-0.005 \\
(0.005)\end{array}$ & $\begin{array}{l}-0.010^{* * *} \\
(0.004)\end{array}$ & $\begin{array}{l}0.814^{*} \\
(0.094)\end{array}$ \\
\hline Part-time employment & $\begin{array}{l}0.076^{* * *} \\
(0.016)\end{array}$ & $\begin{array}{l}0.053^{* * *} \\
(0.009)\end{array}$ & $\begin{array}{l}1.448^{* * *} \\
(0.451)\end{array}$ & $\begin{array}{l}0.038^{* * *} \\
(0.014)\end{array}$ & $\begin{array}{l}0.015^{*} \\
(0.009)\end{array}$ & $\begin{array}{l}1.039 \\
(0.223)\end{array}$ \\
\hline Temporary employment & $\begin{array}{l}0.014^{* * *} \\
(0.005)\end{array}$ & $\begin{array}{l}0.010^{* * *} \\
(0.003)\end{array}$ & $\begin{array}{l}1.247^{* * *} \\
(0.092)\end{array}$ & $\begin{array}{l}0.015^{* *} \\
(0.008)\end{array}$ & $\begin{array}{l}0.004 \\
(0.006)\end{array}$ & $\begin{array}{l}0.886 \\
(0.137)\end{array}$ \\
\hline $\mathrm{P}($ second job $=1)$ & 0.067 & 0.068 & 0.089 & 0.059 & 0.063 & 0.106 \\
\hline Observations/No. of individ. & 54,045 & $54,045 / 11,341$ & $9363 / 1363$ & 40,733 & $40,733 / 7521$ & $7924 / 995$ \\
\hline $\mathrm{Chi}^{2}$ & 543.54 & 693.88 & 345.88 & 405.47 & 430.34 & 202.48 \\
\hline
\end{tabular}

Notes: Marginal effects for Probit and RE Probit, odds ratios for FE Logit; control variables included comprise occupation, industry, region, time, and socio-demographics; (bootstrapped) standard errors in parentheses; ${ }^{* * *} p<0.01,{ }^{* *} p<0.05,{ }^{*} p<0.1$

Source: SOEP 1995, 1997-2007; BHPS 1991-2006

strongly statistically significant coefficients for German workers. Part-time employment for example is associated with an increase of more than five percentage points in the predicted moonlighting probability. The factor change of 1.4 from the fixed effects model also indicates a strong relationship. However, since it is difficult to tell whether males' part-time employment is voluntary or not, both 'hours-constraints' and 'heterogeneous jobs' may work through this.

\subsection{Results for females}

The results for women (Table 4) show only few differences in moonlighting correlates compared to men. Findings for working hours preferences are in accordance with those of males: preferences towards more working hours are associ- ated with a higher moonlighting propensity of German but not of British women; the desire to work fewer hours is negatively related to female moonlighting in the UK but positively related to secondary jobholding in Germany. As noted above, it might be that higher wages in the second job are an incentive for downwards constrained workers to participate in moonlighting.

Dissatisfaction with job security, pay or household-income, and the job itself is no predictor for secondary jobholding of German women. There, however, is some evidence for a higher moonlighting propensity of British women who are not satisfied with their job security. This might be interpreted in light of secondary jobholding serving as a hedge against unemployment for British women. Reinforcing the 'hours-constraints' motive and in line with the findings for males, dissatisfaction with pay is a good 
Table 4 Propensity to moonlight in Germany and the UK, females' samples

\begin{tabular}{|c|c|c|c|c|c|c|}
\hline & \multicolumn{3}{|c|}{ Germany } & \multicolumn{3}{|c|}{ UK } \\
\hline & Probit & RE Probit & FE Logit & Probit & RE Probit & FE Logit \\
\hline Would like to work more hours & $\begin{array}{l}0.024^{* * *} \\
(0.005)\end{array}$ & $\begin{array}{l}0.012^{* * *} \\
(0.003)\end{array}$ & $\begin{array}{l}1.251^{* *} \\
(0.120)\end{array}$ & $\begin{array}{l}0.007 \\
(0.006)\end{array}$ & $\begin{array}{l}0.0005 \\
(0.004)\end{array}$ & $\begin{array}{l}0.936 \\
(0.082)\end{array}$ \\
\hline Would like to work fewer hours & $\begin{array}{l}0.008^{* *} \\
(0.003)\end{array}$ & $\begin{array}{l}0.006^{* *} \\
(0.002)\end{array}$ & $\begin{array}{l}1.228^{* *} \\
(0.103)\end{array}$ & $\begin{array}{l}-0.011^{* * *} \\
(0.004)\end{array}$ & $\begin{array}{l}-0.005^{*} \\
(0.003)\end{array}$ & $\begin{array}{l}0.934 \\
(0.065)\end{array}$ \\
\hline Is dissatisfied with job security & $\begin{array}{l}-0.005 \\
(0.004)\end{array}$ & $\begin{array}{l}0.001 \\
(0.003)\end{array}$ & $\begin{array}{l}1.148 \\
(0.118)\end{array}$ & $\begin{array}{l}0.006 \\
(0.004)\end{array}$ & $\begin{array}{l}0.007^{* *} \\
(0.003)\end{array}$ & $\begin{array}{l}1.142^{*} \\
(0.080)\end{array}$ \\
\hline ... with pay/household-income & $\begin{array}{l}0.006 \\
(0.004)\end{array}$ & $\begin{array}{l}-0.000 \\
(0.003)\end{array}$ & $\begin{array}{l}0.880 \\
(0.089)\end{array}$ & $\begin{array}{l}0.015^{* * *} \\
(0.004)\end{array}$ & $\begin{array}{l}0.012^{* * *} \\
(0.003)\end{array}$ & $\begin{array}{l}1.219^{* * *} \\
(0.077)\end{array}$ \\
\hline ... with job itself & $\begin{array}{l}-0.001 \\
(0.005)\end{array}$ & $\begin{array}{l}-0.004 \\
(0.004)\end{array}$ & $\begin{array}{l}0.874 \\
(0.109)\end{array}$ & $\begin{array}{l}-0.002 \\
(0.004)\end{array}$ & $\begin{array}{l}-0.002 \\
(0.003)\end{array}$ & $\begin{array}{l}0.946 \\
(0.072)\end{array}$ \\
\hline Log of second job wage & $\begin{array}{l}0.018^{* *} \\
(0.008)\end{array}$ & $\begin{array}{l}0.008 \\
(0.006)\end{array}$ & $\begin{array}{l}1.222 \\
(0.166)\end{array}$ & $\begin{array}{l}0.013 \\
(0.009)\end{array}$ & $\begin{array}{l}0.022^{* * *} \\
(0.007)\end{array}$ & $\begin{array}{l}1.297 \\
(0.243)\end{array}$ \\
\hline Log of first job wage & $\begin{array}{l}-0.003 \\
(0.004)\end{array}$ & $\begin{array}{l}-0.010^{* * *} \\
(0.003)\end{array}$ & $\begin{array}{l}0.747^{* * *} \\
(0.069)\end{array}$ & $\begin{array}{l}-0.019^{* * *} \\
(0.006)\end{array}$ & $\begin{array}{l}-0.028^{* * *} \\
(0.004)\end{array}$ & $\begin{array}{l}0.427^{* * *} \\
(0.042)\end{array}$ \\
\hline Log of non-labor income & $\begin{array}{l}-0.002^{* * *} \\
(0.001)\end{array}$ & $\begin{array}{l}-0.003^{* * *} \\
(0.000)\end{array}$ & $\begin{array}{l}0.911^{* * *} \\
(0.010)\end{array}$ & $\begin{array}{l}-0.002^{* * *} \\
(0.000)\end{array}$ & $\begin{array}{l}-0.002^{* * *} \\
(0.000)\end{array}$ & $\begin{array}{l}0.960^{* *} \\
(0.016)\end{array}$ \\
\hline Weekly working hours & $\begin{array}{l}-0.0002 \\
(0.000)\end{array}$ & $\begin{array}{l}-0.0004^{* *} \\
(0.000)\end{array}$ & $\begin{array}{l}0.986^{* * *} \\
(0.004)\end{array}$ & $\begin{array}{l}-0.002^{* *} \\
(0.001)\end{array}$ & $\begin{array}{l}-0.002^{* * *} \\
(0.001)\end{array}$ & $\begin{array}{l}0.956^{* * *} \\
(0.004)\end{array}$ \\
\hline Works overtime & $\begin{array}{l}0.015^{\text {*** }} \\
(0.003)\end{array}$ & $\begin{array}{l}0.009^{* * *} \\
(0.002)\end{array}$ & $\begin{array}{l}1.225^{\text {*** }} \\
(0.088)\end{array}$ & $\begin{array}{l}0.009^{*} \\
(0.006)\end{array}$ & $\begin{array}{l}0.005 \\
(0.004)\end{array}$ & $\begin{array}{l}1.034 \\
(0.094)\end{array}$ \\
\hline Overtime work is paid & $\begin{array}{l}0.005 \\
(0.005)\end{array}$ & $\begin{array}{l}-0.004 \\
(0.003)\end{array}$ & $\begin{array}{l}0.830^{*} \\
(0.083)\end{array}$ & $\begin{array}{l}-0.000 \\
(0.006)\end{array}$ & $\begin{array}{l}-0.002 \\
(0.004)\end{array}$ & $\begin{array}{l}0.989 \\
(0.103)\end{array}$ \\
\hline Part-time employment & $\begin{array}{l}0.012^{* * *} \\
(0.004)\end{array}$ & $\begin{array}{l}0.011^{* * *} \\
(0.003)\end{array}$ & $\begin{array}{l}1.302^{* * *} \\
(0.125)\end{array}$ & $\begin{array}{l}0.024^{* * *} \\
(0.008)\end{array}$ & $\begin{array}{l}0.023^{* * *} \\
(0.005)\end{array}$ & $\begin{array}{l}1.460^{* * *} \\
(0.172)\end{array}$ \\
\hline Temporary employment & $\begin{array}{l}0.011^{* * *} \\
(0.004)\end{array}$ & $\begin{array}{l}0.008^{* * *} \\
(0.003)\end{array}$ & $\begin{array}{l}1.306^{* * *} \\
(0.102)\end{array}$ & $\begin{array}{l}0.013^{*} \\
(0.006)\end{array}$ & $\begin{array}{l}0.010^{*} \\
(0.005)\end{array}$ & $\begin{array}{l}1.119 \\
(0.118)\end{array}$ \\
\hline $\mathrm{P}($ second job $=1)$ & 0.056 & 0.056 & 0.067 & 0.071 & 0.069 & 0.075 \\
\hline Observations/No. of individ. & 47,538 & $47,538 / 10,570$ & $7321 / 1147$ & 43,591 & $43,591 / 8070$ & $11,505 / 1366$ \\
\hline $\mathrm{Chi}^{2}$ & 364.30 & 434.61 & 181.90 & 695.04 & 852.77 & 455.57 \\
\hline
\end{tabular}

Notes: Marginal effects for Probit and RE Probit, odds ratios for FE Logit; control variables included comprise occupation, industry, region, time, and socio-demographics; (bootstrapped) standard errors in parentheses; ${ }^{* * *} p<0.01,{ }^{* *} p<0.05,{ }^{*} p<0.1$

Source: SOEP 1995, 1997-2007; BHPS 1991-2006

predictor for female moonlighting participation in the UK with changes of roughly one percentage point in the predicted probabilities of the probit models.

There is no clear pattern for moonlighting wages, but first job wages, and particularly non-labor income, are strong predictors for females secondary jobholding in both countries: the marginal effects from the random effects models, for example, suggest that a one unit increase in the log of first job wages results in a decrease of moonlighting probability of one percentage point for German women and almost three percentage points for British women. In the fixed effects models, the odds correspondingly change by a factor of 0.7 (Germany) and 0.4 (UK). Furthermore, with somewhat smaller changes in probability and odds, non-labor income is also negatively related to secondary jobholding of women in both countries.
Rather small changes are also found for females' weekly working hours, indicating a negative relation between first job working hours and moonlighting both in Germany and the UK. Similar to the results for males, there is a positive association between working overtime and secondary jobholding for German women indicating a change in the predicted moonlighting probability of about one percentage point. Note again that compensation by leisure instead of pay may be relevant for this finding. Future research might address this in more detail and may also explore the effect of overtime premiums.

Whereas temporary employment is a good predictor for female moonlighting in Germany and somewhat less convincing also in the UK, part-time employment is strongly associated with secondary jobholding of women both in Germany and the UK. The marginal effects from the probit 
regressions suggest increases in the predicted probability of about one percentage point in Germany and even two percentage points for British part-time working women. This corresponds to increases in moonlighting propensity of about $18 \%$ and about $28 \%$ respectively. As mentioned above, it may be that women on the liberal British labor market voluntarily supply labor in two jobs that better suit their needs of flexible working time, for instance when taking care of children. While that argument in general also holds for Germany, it may as well be assumed that part-time occupation is of involuntary nature on the strongly regulated German labor market. Female part-timers may therefore face the need to adjust their working hours in case they want to work more hours. The findings for German women in temporary employment suggest that these jobs may not serve as stepping stones to permanent, higher paying employment that would render moonlighting unnecessary.

\section{Summary and concluding remarks}

This paper adds to the small literature on secondary jobholding providing a comparison of moonlighting determinants for Germany and the UK. The analysis does not focus only on the most prominent theoretical argument of moonlighting, the 'hours-constraints' motive, but also accounts for the 'heterogeneous-jobs' motive as a determining factor. Hours-constraints on the first job cap workers' earnings capacity which may lead them to moonlight. On the other hand, if jobs are not perfect substitutes there might be other reasons for workers to hold a second job. Such might for example include social insurance options, but also non-monetary amenities. Analyzing secondary jobholding for Germany and the UK is thus interesting and relevant since the German labor market is rather strongly regulated while the UK has one of the most liberal labor market regimes.

The results from the empirical analyses provide evidence mainly in support of the 'hours-constraints' motive inasmuch as indicators on earnings capacity are associated with moonlighting. However, effects vary both across gender and country. For example, hours-constraints seem to play a more important role for German workers in their decision to moonlight. The evidence in support of the 'heterogeneous-jobs' motive is weaker which however is a data issue. Part-time employment, for example, is a good predictor for secondary jobholding in both countries. However, it is difficult to tell whether this supports the hours-constraints motive - which would be the case if holding a part-time job is involuntarily - or whether the two part-time jobs are freely chosen - which would be in line with the heterogeneous jobs motive.
Summing up, there are more similarities than discrepancies in secondary jobholding determinants in Germany and the UK meaning that the differences in labor market regimes do only partially transmit into individual labor supply behavior that differs with respect to moonlighting.

As for future research, it may be worthwhile to address the types of first and second jobs in more detail which could be helpful for examining whether jobs are substitutes or complements. Analyses of moonlighting duration or cyclicality may also help to get a more comprehensive view of individuals' labor supply. Addressing the relationship between overtime, overtime compensation and moonlighting might be interesting from a policy point of view inasmuch as working time regulations may not result in generating new jobs for regular full- or part-time worker but rather attracts workers who need or prefer to work in more than one job.

\section{Executive summary}

This paper examines participation in secondary jobholding in Germany and the UK using longitudinal data from the German Socio-Economic Panel Study (SOEP) and the British Household Panel Survey (BHPS), spanning the time from 1991 to 2007. The analysis does not focus only on the early and still most prominent theoretical notion, the 'hours-constraints' motive, but also accounts for the 'heterogeneous-jobs' motive. Hours-constraints on the first job cap workers' earnings capacity which may lead them to moonlight in order to adjust to the desired level of working time. If, however, jobs are not perfect substitutes, there might be other reasons to hold a second job, such as social insurance options, but also non-monetary amenities. Analyzing secondary jobholding for Germany and the UK is thus informative since the German labor market is rather strongly regulated while the UK has one of the most liberal labor market regimes.

The empirical analyses first indicate that secondary jobholding is a persistent phenomenon in both countries. Over the time period considered, there on average are moonlighting shares of $7 \%$ in Germany and almost $8 \%$ in the UK. Yet, participation varies over time, by gender, and by full- and part-time employment. The findings from multiple regressions then provide evidence mainly in support of the 'hours-constraints' motive inasmuch as indicators on earnings capacity are associated with moonlighting. Again, effects vary both across gender and country. Hoursconstraints, for example, seem to play a more important role for German workers in their decision to moonlight. The evidence in support of the 'heterogeneous-jobs' motive is weaker which is a data issue. Part-time employment, 
for example, is a good predictor for secondary jobholding in both countries. It, however, is difficult to tell whether this finding supports the hours-constraints motive or the heterogeneous jobs motive as no indicators are available on whether working part-time is chosen freely or not.

Summing up, the differences in labor market regimes in Germany and the UK do only partially transmit into differences in moonlighting behavior.

\section{Kurzfassung}

Die Studie untersucht für den Zeitraum von 1991 bis 2007 die Determinanten der Nebenerwerbstätigkeit in Deutschland und im Vereinigten Königreich unter Verwendung von Daten des Sozio-Ökonomischen Panels (SOEP) für Deutschland und des British Household Panel Survey (BHPS) für das Vereinigte Königreich. Die Analyse beschränkt sich hierbei nicht nur auf das frühe und nach wie vor bedeutsamste theoretische Argument der Beschränkung realisierbarer Arbeitszeit, sondern trägt auch dem Heterogenitätsmotiv Rechnung. Beschränkungen der realisierbaren Arbeitszeit im Haupterwerb beschneiden die Verdienstmöglichkeiten, was zu einem Anreiz führen kann, eine weitere Erwerbstätigkeit aufzugreifen, um sich hierdurch zum gewünschten Niveau an Arbeitszeit und mithin Verdienst anzunähern.

Falls zudem Tätigkeiten keine perfekten Substitute sind, ist es möglich, dass andere Beweggründe greifen, die zu einer Nebenerwerbstätigkeit führen. Beispiele hierfür sind Aspekte sozialer Sicherung oder andere, nicht-monetäre
Eigenschaften der Tätigkeit. Der Vergleich der Nebenerwerbstätigkeit Deutschland/Vereinigtes Königreich ist insofern informativ, da sich der institutionelle Rahmen der Arbeitsmärkte deutlich unterscheidet: der deutsche Arbeitsmarkt ist ein weitgehend regulierter, der britische hingegen einer der liberalsten weltweit.

Die empirischen Analysen zeigen zunächst, dass Nebenerwerbstätigkeit ein beständiges Phänomen in beiden Ländern ist. So ergibt sich für den betrachteten Zeitraum im Mittel eine Nebenerwerbstätigkeits-Quote von 7\% in Deutschland und fast $8 \%$ im Vereinigten Königreich, was gleichwohl über die Zeit, nach Geschlecht sowie nach Vollzeit- und Teilzeitbeschäftigung variiert. Die Befunde multipler Regressionen stützen sodann eher die Hypothesen der Beschränkung realisierbarer Arbeitszeiten, wiederum mit Unterschieden in Abhängigkeit von Geschlecht und Land. So spielen für die Nebenerwerbstätigkeitsbeteiligung z. B. Beschränkungen der tatsächlichen Arbeitszeit eine höhere Rolle für deutsche Erwerbstätige. Die Evidenz in Bezug auf das Heterogenitätsmotiv ist weniger überzeugend, was aber eher auf die Daten zurückgeführt werden kann. In beiden Ländern ist z. B. Teilzeitbeschäftigung ein guter Prädiktor für Nebenerwerbstätigkeit. Es ist jedoch nicht eindeutig, ob dieses Ergebnis das StundenBeschränkungsmotiv oder das Heterogenitätsmotiv stützt, da aus den Daten keine Information über die Freiwilligkeit der Teilzeitbeschäftigung hervorgeht.

Zusammenfassend lässt sich gleichwohl sagen, dass sich die Unterschiede in den Arbeitsmarktregimen nur teilweise auf das Nebenerwerbstätigkeitsverhalten in beiden Ländern niederschlagen. 


\section{Appendix A}

Table 5 Descriptive statistics

\begin{tabular}{|c|c|c|c|c|}
\hline & $\begin{array}{l}\text { Germany } \\
\text { Mean }\end{array}$ & Std. Dev. & $\begin{array}{l}\text { UK } \\
\text { Mean }\end{array}$ & Std. Dev. \\
\hline Has a second job & 0.069 & $(0.253)$ & 0.075 & $(0.264)$ \\
\hline Male & 0.532 & $(0.498)$ & 0.483 & $(0.499)$ \\
\hline Age & 39.666 & $(10.891)$ & 38.665 & $(10.845)$ \\
\hline Is married & 0.621 & $(0.485)$ & 0.771 & $(0.419)$ \\
\hline Has children, aged $0-4$ years & 0.444 & $(0.496)$ & 0.136 & $(0.343)$ \\
\hline Has children, aged $5-15$ years & 0.122 & $(0.374)$ & 0.333 & $(0.471)$ \\
\hline Spouse is employed & 0.473 & $(0.787)$ & 0.631 & $(0.482)$ \\
\hline Would like to work more hours & 0.160 & $(0.367)$ & 0.072 & $(0.254)$ \\
\hline Would like to work the same hours & 0.272 & $(0.445)$ & 0.593 & $(0.491)$ \\
\hline Would like to work fewer hours & 0.567 & $(0.495)$ & 0.335 & $(0.470)$ \\
\hline Is dissatisfied with job security & 0.156 & $(0.363)$ & 0.223 & $(0.416)$ \\
\hline Is dissatisfied with pay (UK)/income (D) & 0.099 & $(0.299)$ & 0.319 & $(0.466)$ \\
\hline Is dissatisfied with work itself & 0.059 & $(0.237)$ & 0.178 & $(0.382)$ \\
\hline Log of gross second job wage, observed & 2.806 & $(1.012)$ & 2.103 & $(1.003)$ \\
\hline Log of gross first job wage & 2.315 & $(0.574)$ & 1.695 & $(0.459)$ \\
\hline Log of non-labor income & 4.613 & (3.262) & 4.147 & $(2.167)$ \\
\hline Weekly working hours (first job) & 38.330 & $(11.769)$ & 38.493 & $(12.953)$ \\
\hline Works overtime & 0.491 & $(0.499)$ & 0.463 & $(0.498)$ \\
\hline Overtime is paid & 0.149 & $(0.356)$ & 0.255 & $(0.435)$ \\
\hline Part-time employment & 0.174 & $(0.379)$ & 0.192 & $(0.394)$ \\
\hline Temporary employment & 0.245 & $(0.430)$ & 0.049 & $(0.215)$ \\
\hline Has recently changed job & 0.151 & $(0.358)$ & 0.288 & $(0.452)$ \\
\hline Job duration (in years) & 9.682 & $(9.401)$ & 4.599 & $(5.900)$ \\
\hline Has a public employer & 0.273 & $(0.445)$ & 0.189 & $(0.391)$ \\
\hline Schooling: Abitur (D) & 0.409 & $(0.566)$ & - & - \\
\hline Schooling: Realschule (D) & 0.356 & $(0.482)$ & - & - \\
\hline Schooling: Hauptschule (D) & 0.235 & $(0.424)$ & - & - \\
\hline Schooling: First or higher degrees (UK) & - & - & 0.412 & $(0.492)$ \\
\hline Schooling: A-levels (UK) & - & - & 0.124 & $(0.330)$ \\
\hline Schooling: O-levels (UK) & - & - & 0.283 & $(0.450)$ \\
\hline Schooling: CSE-levels (UK) & - & - & 0.126 & $(0.332)$ \\
\hline Firm size dummies & + & - & + & - \\
\hline Occupation dummies (first job) & + & - & + & - \\
\hline Industry dummies (first job) & + & - & + & - \\
\hline Region dummies & + & - & + & - \\
\hline Time dummies & + & - & + & - \\
\hline $\mathrm{N}$ & 84,324 & - & 101,589 & - \\
\hline
\end{tabular}

Source: SOEP 1995, 1997-2007; BHPS 1991-2006 


\section{References}

Allen, W.D.: The moonlighting decision of unmarried men and women: Family and labor market influences. Atl. Econ. J. 26(2), 190-205 (1998)

Amuedo-Dorantes, C., Kimmel, J.: Moonlighting behavior over the business cycle. IZA Discuss. Pap. 1672 (2005)

Averett, S.L.: Moonlighting: multiple motives and gender differences. Appl. Econ. 33(11), 1391-1410 (2001)

Bell, D.N., Hart, R.A., Wright, R.E.: Multiple job-holding as a 'hedge' against unemployment. CEPR Discuss. Pap. 1626 (1997)

Böheim, R., Taylor, M.P.: And in the evening she's a singer with a band - second jobs, plight or pleasure. ISER Work. Pap. 03 (2004a)

Böheim, R., Taylor, M.P.: Actual and preferred working hours. Br. J. Ind. Relat. 42(1), 149-166 (2004b)

Bryan, M.L.: Free to choose? Differences in the hours determination of constrained and unconstrained workers. Oxf. Econ. Pap. 59(2), 226-252 (2007)

Caliendo, M., Wrohlich, K.: Evaluating the German "Mini-Job" reform using a true natural experiment. IZA Discuss. Pap. 2041 (2006)

Heckman, J.J.: Sample selection bias as a specification error. Econometrica 47(1), 153-161 (1979)

Heineck, G., Schwarze, J.: Auswirkungen der Einführung der Sozialversicherungspflicht für geringfügige Beschäftigung - Eine Evaluation des ,630-DM-Jobs“ Reformgesetzes. Mitt. Arbeitsmarkt- und Berufsforsch. 34(3), 314-327 (2001)

Highfill, J.K., Felder, J., Sattler, E.L.: Multiple worker households and multiple job holding: Rigid vs. flexible hours. Am. Econ. 39(1), 40-47 (1995)

Hirschenauer, F., Wießner, F.: Mehrfachbeschäftigung - Ein Job ist nicht genug. IAB Kurzber. 22/6.12.2006 (2006)

Kimmel, J., Powell, L.M.: Moonlighting trends and related policy issues in Canada and the United States. Can. Public Policy 25(2), 207-231 (1999)

Kimmel, J., Smith Conway, K.: Who moonlights and why? Ind. Relat. 40(1), 89-120 (2001)

Marshall, K.: The duration of multiple jobholding. Perspect. Labour and Income 3(4), 17-23 (2002)

Nickell, S., Nunziata, L., Ochel, W.: Unemployment in the OECD since the 1960s. What do we know? Econ. J. 115, 1-27 (2005)

OECD: Employment Outlook. OECD, Paris (1999)

Paxson, C.H., Sicherman, N.: The dynamics of dual job holding and job mobility. J. Labor Econ. 14(3), 357-393 (1996)

Puhani, P.A.: Foul or fair? The Heckman correction for sample selection and its critique - A short survey. J. Econ. Surv. 14(1), 53-68 (2000)
Renna, F.: Overtime and Moonlighting: A Cross-Country Analysis. J. Labor Res. 27(4), 575-591 (2006)

Schmitt, C.: Labour market integration and the transition to parenthood - A comparison of Germany and the UK. SOEPpapers 119 (2008)

Schwarze, J.: Nebenerwerbstätigkeit in der Bundesrepublik Deutschland. Umfang und Ursachen von Mehrfachbeschäftigung und Schattenwirtschaft. Campus, Frankfurt (1991)

Schwarze, J.: Nebenerwerbstätigkeit in Deutschland nimmt zu - Zur Frage der Versicherungspflicht. DIW-Wochenber. 64(22), 406412 (1997)

Schwarze, J., Heineck, G.: Rückgang der Nebenerwerbstätigkeit durch Einführung der Sozialversicherungspflicht wird überschätzt. DIW-Wochenber. 66(37), 661-666 (1999)

Shishko, R., Rostker, B.: The Economics of Multiple Jobholding. Am. Econ. Rev. 66(3), 298-308 (1976)

Smith Conway, K., Kimmel, J.: Male labor supply and the decision to moonlight. Labour Econ. 5, 135-66 (1998)

Sousa-Poza, A., Henneberger, F.: An empirical analysis of workinghours constraints in twenty-one countries. Rev. Soc. Econ. 60(2), 209-242 (2002)

Stinson, J.F.: New data on multiple jobholding available from the CPS. Mon. Labor Rev. 120(3), 3-8 (1997)

Sussman, D.: Moonlighting: A growing way of life. Perspect. Labor Income 10(2), 24-31 (1998)

Taylor, M.F., Brice, J., Buck, N., Prentice-Lane, E. (Hrsg.): British Household Panel Survey User Manual Volume A: Introduction, Technical Report and Appendices. University of Essex, Colchester (2008)

Wagner, G.G., Frick, J.R., Schupp, J.: The German Socio-Economic Panel Study (SOEP) - Scope, Evolution and Enhancements. Schmollers Jahrb. 127(1), 139-169 (2007)

Guido Heineck, Economics studies at the University of Bamberg, graduation in 1998: Dipl.-Volkswirt (M.Sc. equivalent). Research assistant at the University of Bamberg from 1998 to 2003, Ph.D. in Economics in 2004. Since February 2009 Head of the Research Department "Education and Employment over the Life Course" at the Institute for Employment Research (IAB).

Research interests: Labour supply and determinants of earnings, international comparative studies, intergenerational transmission of education and skills.

guido.heineck@iab.de 